\title{
KONSTITUSIONALITAS PESANTREN PASKA DISAHKANNYA UU 18 TAHUN 2019
}

\author{
Erfandi \\ Dosen Tamu di Ilmu Hukum Universitas Nahdlatul Ulama Indonesia \\ Email : erfandi20@gmail.com
}

\begin{abstract}
Abstrak
Konstitusionalitas Pesantren di Indonesia mengalami dinamika yang sangat Panjang. Mulai dari aspek sejarah berdirinya Pesantren, fungsi pesantren sampai diperbolehkannya Pesantren melakukan kerjasama dengan dunia luar negeri. Negara seakan tidak hadir terhadap keberlangsungan Pesantren, meskipun Pesantren merupakan pendidikan pertama yang memiliki cirri khas dibandingkan dengan pendidikan di luar Indonesia. Namun menjadi berbeda, keberadaan Pesantrn dan pengakuan syahadah sebagai ijazah Pesantren semakin diakui paska disahkannya UU 18 Tahun 2019 Tentang Pesantren disahkan oleh Parlemen bersama pemerintah.
\end{abstract}

Kata Kunci : Pesantren, UU 18 Tahun 2019 Tentang Pesantren

\begin{abstract}
The constitutionality of Islamic boarding schools in Indonesia is experiencing a very long dynamic. Starting from the historical aspect of the establishment of the Islamic boarding school, the function of the pesantren to allowing the pesantren to collaborate with the world abroad. The state seems to be absent from the existence of Islamic boarding schools, although pesantren is the first education that has distinctive characteristics compared to education outside Indonesia. However, to be different, the existence of Islamic boarding schools and the recognition of syahadah as pesantren certificates were increasingly recognized after the passage of Law 18 of 2019 on Islamic boarding schools was passed by the Parliament together with the government.
\end{abstract}

Key Word : boarding school, Law 18 of 2019 on Islamic boarding schools

\section{Pendahuluan}

\subsection{Latar Belakang}

Pesantren merupakan sistem pendidikan khas yang dimiiki oleh Indonesia. Bahkan eksistensi Pesantren ada sebelum Indonesia mendeklarasikan dirinya sebagai negara yang merdeka. Pesantren dengan segala dinamikanya sudah berdiri seiring dengan masuknya Islam ke tanah nusantara. Bahkan, pada abad ke 17 (era keemasan Wali Songo), pesantren tidak hanya berfungsi sebagai pendidikan semata. Dalam era ini, Pesanten mulai memainkan perannya 
pada ranah dakwah dan peran politis. Taruhlah pada masa kerajaan Demak dan Pajang, Pesantren memiliki posisi sentral dalam ikut menentukan kebijakan yang akan dikeluarkan oleh kerajaan Demak atau Pajang saat itu.

Peran Pesantren pada gilirannya juga memberikan inspirasi pada pembentukan pondasi Negara Kesatuan Republik Indonesia. ${ }^{1}$ Melalui founding father perumus kemerdekaan Indonesia, nilai-nilai yang diajarkan Pesantren masuk pada substansi bernegara. Misalnya peletakan dasar sila-sila dalam Pancasila. Terlepas dari perdebatan butir dalam sila pada tanggal 29 Mei, 22 Juni hingga dicapai kesepakatan pada tanggal 18 Agustus 1945, yang pasti nilai Pesantren diadopsi dan disepakatai oleh pendiri bangsa untuk memasukkan nilai Ketuhanan dalam Pancasila. Tidak berhenti pada Pancasila sebagai staat fundametal norm atau philosophische grondslag dalam bernegara. Nilai pendidikan dalam pesantren juga menjadi rujukan dalam pendidikan nasional. Bahkan jika kita merujuk pada cita-cita reformasi salah satunya adalah terwujudnya penegakan supremasi hukum dan penghormatan kepada hak asasi manusia. ${ }^{2}$ Sehingga sudah sewajarnya pendidikan itu bisa dinikmati oleh semua anak bangsa dengan berbagai latar belakang pendidikannya.

Peran pesantren yang dalam perjalanan sejarahnya tidak hanya berfungsi dalam peningkatan pendidikan, tapi juga memerdekakan setiap orang dari segala bentuk macam penjajahan, ditegaskan dalam Pembukaan UUD 1945 alinea IV yang berbunyi: “Kemudian dari pada itu, untuk membentuk suatu Pemerintahan Negara Indonesia yang melindungi segenap Bangsa Indonesia dan seluruh tumpah darah Indonesia dan untuk memajukan kesejahteraan umum, mencerdaskan kehidupan bangsa, dan ikut melaksanakan ketertiban dunia yang berdasarkan kemerdekaan, perdamaian abadi dan keadilan sosial maka disusunlah kemerdekaan kebangsaan Indonesia itu dalam suatu Undang-Undang Dasar Negara Indonesia, yang terbentuk dalam suatu susunan Negara Republik Indonesia yang berkedaulatan rakyat dengan berdasarkan kepada: Ketuhanan Yang Maha Esa, Kemanusiaan yang adil dan beradab, Persatuan Indonesia dan Kerakyatan yang dipimpin oleh hikmat kebijaksanaan dalam

\footnotetext{
${ }^{1}$ Selain sebagai tempat Pendidikan, pesantren juga sebagai simbol pergerakan kemeredakaan. Banyak tokoh tokoh penggerak kemerdekaan yang juga diskusi di lingkungan pesantren, seperti Tan Malaka yang sering silaturrahim ke Pesantren Tebu Ireng, Jombang. Lengkapnya baca Muhtar Said (all), Politik Hukum Tan Malaka, Thafa Media, Yogyakarta, 2013

${ }^{2}$ Arinanto, Satya; Politik Pembangunan Huku Nasional Dalam Era Paska Reformasi: Jurnal Konstitusi Mahkamah Konstitusi, 2006 hlm 73
} 
permusyawaratan perwakilan, serta mewujudkan suatu Keadilan sosial bagi seluruh rakyat Indonesia”.

Namun dalam perjalanannya, Indonesia merdeka yang didirikan atas kehendak segenap bangsa tanpa membeda-bedakan suku ras dan dari mana unsurnya, ternyata masih mendikhotomikan sistem pendidikan pesantren dengan sistem pendidikan umum. Negara yang didirikan oleh berbagai komponen, dalam prakteknya sering memandang sebelah mata antara pendidikan pesantren dengan pendidikan umum. Stigma Pesantren sebagai kelas nomor 2 semakin terjadi paska syahadah sebagai ijazah pesantren yang tidak mendapat respon positif ketika santri mau melajutkan ke jenjang perguruan tinggi atau tempat kerja.

Penerjemahan tentang kata 'mencerdaskan kehidupan bangsa' sebagaimana yang tertuang dalam Pasal 31 ayat (1) 'Setiap warga negara berhak mendapat pendidikan,' ayat (2) Setiap warga negara wajib mengikuti pendidikan dasar dan pemerintah wajib membiayainya', ayat (3) Pemerintah mengusahakan dan menyelenggarakan satu sistem pendidikan nasional, yang meningkatkan keimanan dan ketakwaan serta akhlak mulia dalam rangka mencerdaskan kehidupan bangsa, yang diatur dengan Undang-Undang, ayat (4) 'negara memprioritaskan anggaran pendidikan sekurang-kurangnya dua puluh persen dari anggaran pendapatan dan belanja negara serta dari anggaran pendapatan dan belanja daerah untuk memenuhi kebutuhan penyelenggaraan pendidikan nasional,' ayat (5)'Pemerintah memajukan ilmu pengetahuan dan teknologi dengan menjunjung tinggi nilai-nilai agama dan persatuan bangsa untuk kemajuan peradaban serta kesejahteraan umat manusia. '3 seakan-akan hanya menjadi hak dari pendidikan umum tidak untuk Pesantren.

Dari latar belakang diatas maka artikel ini akan membahasan Bagaimana Posisi Hukum Pendidikan Pesantren sebelum dan Sesudah Diundangkannya Undang-Undang Nomor 18 Tahun 2019 Tentang Pesantren?.

\subsection{Metode Penelitian}

Penyusunan penulisan ini dilakukan dengan metode yuridis normative atau doktrinal dengan statute approach melalui studi perundang-undangan dan kepustakaan/literatur dengan menelaah berbagai data dan doktrin hukum yang berkaitan dengan pesantren. Sehingga

\footnotetext{
${ }^{3}$ Sekretariat Jenderal MPR RI, Undang-Undang Dasar Negera Republik Indonesia Tahun 1945 (Jakarta, Setjen MPR RI, 2014), Cet.XIII, hlm. 15-16.
} 
regulasi dan literature yang berhubungan dengan pesantren menjadi rujukan dalam penulisan Nasib Pesanttren Paska disahkannya UU 18 Tahun 2019 ini.

\section{Pembahasan}

\subsection{Kondisi Pesantren Sebelum UU 18 Tahun 2019}

Sejatinya jauh sebelum kemerdekaan Indonesia, pendidikan pesantren sudah ada di Indonesia. Salah satunya Pendidikan Islam yang cukup terkenal di Jawa Timur pada masa penjajahan Belanda tepatnya pendidikan yang berdiri di Tebuireng, yaitu pesantren yang didirikan oleh KH. Hasyim Asy'ari pada tahun 1904 M. Pada mulanya hanya diajarkan agama dan bahasa Arab, kemudian setelah berdiri madrasah salafiyah yang memasukkan ilmu-ilmu umum, seperti ilmu bintang, ilmu bumi dan lain-lain. Pondok Pesantren Tebuireng terdiri atas empat bagian, yaitu: Madrasah Ibtidaiyah (lamanya 6 tahun), Madrasah Tsanawiyah (3 tahun), Mualimin (5 tahun), Pesantren dengan sistem halaqah. Pendidikan Islam di Jawa Timur pada masa penjajahan Belanda tidak terlepas dari pengaruh organisasi Nahdhatul Ulama yang didirikan pada tanggal 16 Rajab 1344 H (3 Januari 1926) di Surabaya. Selain itu, di Yogyakarta juga lahir pendidikan pesantren di Krapyak dan Kweekschool Muhammadiyah, Mualimat dan Tabligh School, pada masa penjajahan Belanda banyak didominasi oleh organisasi Muhammadiyah. Diantaranya yang terkenal adalah. Model pendidikannya dengan menggabungkan antara pelajaran umum dengan agama. Bahkan pada tahun 1905 di Batavia melahirkan madrasah tertua yaitu Jamiat Kheir mulai dari tingkat Tahdiriyah (1 tahun), tingkat Ibtidaiyah (6 tahun), tingkat Tsanawiyah (3 tahun), Bagi lulusan terbaik Tsanawiyah bisa melanjutkan ke Mesir atau Mekkah. Madrasah lain yang juga punya andil besar bagi pendidikan Islam adalah madrasah Al-Irsyad yang didirikan pada tahun 1913. Pendidikan keagamaan tidak hanya tumbuh di Batavia, namun pada perkembangannya juga menjamur di Sulawesi, Kalimantan dan Sumatera. Kebanyakan madrasah di Sulawesi pada mulanya dipimpin oleh guru-gur agama dari Minangkabau dan Yogyakarta. Madrasah yang cukup terkenal di Sulawesi Selatan adalah madrasah Amiriyah Islamiyah di Bone. Mata

pelajaran yang diberikan di madrasah ini meliputi pelajaran agama dan pelajaran umum. di Kalimantan pada masa penjajahan Belanda adalah madrasah Najah Wal Falah di Sei Bakau Besar Mempawah. Didirikan pada tahun 1918 M., setelah itu berdiri madrasah Perguruan Islam Assulthaniyah di Sambas pada tahun 1922 M. 
Perjalanan sejarah pendidikan Keagamaan di era penjajahan Belanda lenyap setelah Jepang berada di Indonesia. Mereka bertekuk lutut tanpa syarat kepada Jepang. Tujuan Jepang ke Indonesia adalah menjadikan Indonesia sebagai sumber daya alam dan sumber daya manusia melalui penanaman ideologi baru yang disebut dengan Ideologi Hakko Ichiu atau ideologi bersama di Asia Timur Raya yang sangat besar artinya bagi kelangsungan perang Pasifik. Hal ini sesuai dengan cita-cita politik ekspansinya.

Dengan melihat realitas dan urgensi pendidikan keagmaan dalam problematika kebangsaan diatas, maka pendidikan keagamaan menjadi sangat dibutuhkan dalam menjiwai kehidupan bernegara. Tak heran jika dalam Pancasila, dimensi ketuhanan menjadi hal yang utama serta menjiwai sila yang lainnya. Selain itu Undang-Undang Dasar Negara Republik Indonesia Tahun 1945 Pasal 31 ayat (3) mensyaratkan bahwa: "Pemerintah mengusahakan dan menyelenggarakan satu Sistem Pendidikan Nasional yang meningkatkan keimanan dan ketakwaan serta akhlak mulia dalam rangka mencerdaskan kehidupan bangsa yang diatur dengan undang-undang”. Atas dasar amanat Undang-Undang Dasar 1945 tersebut, UndangUndang Nomor 20 Tahun 2003 tentang Sistem Pendidikan Nasional pada Pasal 3 menyatakan bahwa Pendidikan Nasional bertujuan untuk berkembangnya potensi peserta didik agar menjadi manusia yang beriman dan bertakwa kepada Tuhan Yang Mahan Esa, berakhlak mulia, sehat, berilmu, cakap, kreatif, mandiri, dan menjadi warga negara yang demokratis serta bertanggung jawab. Dalam Penjelasan Umum Undang-Undang Nomor 20 Tahun 2003 tentang Sistem Pendidikan Nasional ditegaskan bahwa strategi pertama dalam melaksanakan pembaruan Sistem Pendidikan Nasional adalah "pelaksanaan pendidikan agama dan akhlak mulia".

Melihat perjalanan sejarah diatas, nasib Pesantren sangatlah berbeda antara sebelum dengan sesudah disahkannya UU Pesantren. Sebelum UU Pesantren disahkan, Penggambaran fakta disparitas anggaran tersebut dapat dicontohkan pada lembaga pendidikan di Pesantren. Umumnya madrasah yang didirikan masyarakat dalam kondisi keterbatasan yang sangat memprihatinkan dalam berbagai hal. Bagi sementara masyarakat yang lebih dipentingkan adalah simbol yang disandangnya, yakni bernama madrasah. Adapun isi pendidikan maupun hasil yang sebenarnya kurang memperoleh pertimbangan dan perhatian saksama. Kesadaran simbolik, berupa identitas yang disandang, oleh sementara masyarakat ternyata dikalahkan oleh ukuran-ukuran lainnya yang ditetapkan oleh pemerintah sekalipun. Pada umumnya satu- 
satunya penyangga financial kehidupan madrasah adalah wali murid sendiri. Sekalipun madrasah berada di bawah yayasan, tidak berarti bahwa yayasan tersebut mampu mencukupi seluruh kebutuhan madrasah. Pendanaan yang bersumber masyarakat, sesungguhnya tidak mencukupi, baik yang dibayar awal masuk atau bulanan. Besarnya dana yang dipungut dari wali murid itu, umumnya juga tidak besar, apalagi madrasah yang berlokasi di daerah masyarakat miskin, amat kecil. Akibatnya, dana yang dapat dikumpulkan oleh madrasah juga kecil. Kecilnya dana pendukung ini otomatis akan berpengaruh pada kecilnya kemungkinan madrasah memberikan insentif pada guru dan juga penyediaan sarana dan prasarana pendidikan dan kualitas serta mutu pendidikan madrasah. ${ }^{4}$

\subsection{Dasar Hukum Pengaturan Pesantren Sebelum Disahkannya UU 18 Tahun 2019}

Dalam upaya memberikan perhatian itu, pemerintah perlu membentuk aturan jelas dan baku sebagai payung hukum dalam pelaksanaannya. Di sinilah posisi urgensitas kehadiran RUU tentang Pendidikan Keagamaan ini dirumuskan. Harapannya, pemerintah memiliki kekuatan hukum di dalam memberikan perhatian dan mengayomi pendidikan keagamaan. Adapun landasan hukum yang dijadikan pijakan selama ini belum menyentuh secara konkrit pada ranah pendidikan keagamaan secara spesifik. Setidaknya ada dua Undang-undang yang dapat dijadikan acuan dalam konteks ini, yaitu UU nomor 20 tahun 2003 tentang Sistem Pendidikan Nasional, dan UU nomor 12 tahun 2012 tentang Pendidikan Tinggi. Dari dua UU tersebut belum terlihat jelas secara spesifik pengaturan tentang pendidikan keagamaan. Undang-undang no. 20 tahun 2003 tentang Sistem Pendidikan Nasional hanya membahas tentang pendidikan secara formal. Ini menyisakan persoalan di mana Lembaga Pendidikan Keagamaan dan Pesantren yang notabene berada pada wilayah informal belum tersentuh.

Ada legalitas yang sudah bisa dianggap menyentuh persoalan pendidikan keagamaan, tetapi secara hirarkis masih lemah, karena hanya diatur pada tingkatan Peraturan Menteri atau bahkan masih Keputusan Direktur. ${ }^{5}$ Hal ini bisa dilihat pada Peraturan Pemerintah nomor 55 tahun 2007 tentang Pendidikan Agama dan Pendidikan Keagamaan. Dalam Peraturan Pemerintah nomor 55 tahun 2007 tentang Pendidikan Agama dan Pendidikan Keagamaan mengatur

${ }^{4}$ Arifin Junaidi, Pendidikan dan Bonus Demografi, makalah, disampaikan pada FGD Tasheh NA\&RUU Madrasah, 22-23 Juni 2016

${ }^{5}$ Ranah ini merupakan ranah kebijakan eksekutif yang sifatnya bisa dibilang sebagai diskresi, dimana tidak ada peraturan yang mengatur kemudian inisiatif pejabat yang berwenang untuk memberikan legalitas Pendidikan pesantren maka dibuatkanlah aturan. Model aturan yang muncul karena diskresi ini sah karena memang kewenangan pemerintah. Baca Muhtar Said, Asas Asas Hukum Administrasi Negara, Thafa Media, Yogyakarta 2019. 
tentang bagaimana urgensi pendidikan keagamaan bagi generasi umat agama di Indonesia. Persoalannya, bagaimana eksistensi dari Lembaga Pendidikan Keagamaan dan Pesantren sebagai wadah dan pelaksana pendidikan keagamaan belum tersentuh. Di dalam Peraturan Pemerintah nomor 55 tahun 2007 dijelaskan bahwa pendidikan keagamaan merupakan pendidikan yang mempersiapkan peserta didik untuk dapat menjalankan peranan yang menuntut penguasaan pengetahuan tentang ajaran agama dan/atau menjadi ahli ilmu agama dan mengamalkan ajaran agamanya. Hanya saja, peraturan pemerintah ini belum mengatur bagaimana keberadaan lembaganya sebagai sesuatu yang niscaya dalam menjalankan pendidikan keagamaan.

Selain itu, ada juga Keputusan Presiden nomor 22 tahun 2015 tentang Hari Santri, Peraturan Menteri Agama RI Nomor 13 Tahun 2014 tentang Pendidikan Keagamaan Islam, Peraturan Menteri nomor 18 Tahun 2015 tentang Satuan Pendidikan Muadalah pada pondok pesantren, Peraturan Menteri Agama RI nomor 71 Tahun 2015 tentang Ma'had Aly, Keputusan Direktur Jenderal Pendidikan Islam nomor 5877 Tahun 2014 tentang Pedoman Izin Operasional Pondok Pesantren, Keputusan Direktur Jenderal Pendidikan Islam nomor 5839 Tahun 2014 tentang Pedoman Pendirian Pendidikan Diniyah Formal. Semua peraturan tersebut merupakan regulasi yang hanya mengatur tentang pendidikan dalam agama Islam. RUU Pendidikan Keagamaan ini diproyeksikan sebagai landasan hukum bagi lembaga-lembaga pendidikan keagamaan seluruh agama yang ada di Indonesia.

Namun semua dasar hukum mengenai Pesantren sebagai disebutkan diatas, merupakan aturan teknis. Dimana menurut UU 12 Tahun 2011 sebagaimana diubah dengan UU 15 Tahun 2019 Tentang Perubahan UU 12 Tahun 2011 Tentang Pembentukan Peraturan perundang-undangan, materi muatan dalam aturan teknis tidak dapat mengatur anggaran dan atau mengatur materi Pidana.

Atas dasar itu, maka muncul usulan dibentuknya Rancangan Undang-undang yang secara spesifik mengatur tentang Pesantren. Kehadiran negara pada urusan keagamaan, harus memperoleh legalitas, baik untuk membimbing, memfasilitasi maupun mengevaluasi, agar bertindak benar, dan terhindar dari kesalahan-kesalahan substantif serta administratif. Begitu juga para pengelola, agar mereka mengarahkan peserta didiknya untuk menjadi warga negara yang patriot, mencintai negaranya, berkomitmen terhadap persatuan dan kesatuan bangsa 
dalam bingkai NKRI, dan mengikuti Pancasila sebagai falsafah hidup berbangsa dan bernegara.

\subsection{Konstitusionalitas Pesantren Paska UU 18 Tahun 2019}

Legalitas Pesantren dalam UU 18 Tahun 2019 bukan diposisikan sebagai lembaga pendidikan yang harus ijin kepada pemerintah. Dalam UU Pesantren legalitas Pesantren bukan dimasukkan dalam komponen ijin melainkan pada rezim daftar. Artinya tidak ada kewajiban bagi Pesantren untuk permohonan ijin untuk mendirikan Pesantren melainkan hanya daftar. Rejim pendaftaran dalam UU Pesantren ini memberikan kebebasan bagi Pesntren untuk mendaftarkann atau tidak mendaftarkan pesantren kepada pemerintah. Norma pengaturan Pesantren ini dimaksudkan untuk menajaga netralitas pesantren yang selama ini sudah berjalan beberapa dekade.

Sebagaimana disebutkan dalam pasal 6 ayat 2 yang menyebutkan pendirian pesantren cukup memberitahukan kepala desa atau mendaftarkan keberadaannya kepada menteri. Norma ini tidak mengenal perijinan terhadap Pesantren. Selama Pesantren berkomitmen mengamalkan ajaran islam yang rahmatal lil alamin dan tidak bertentangan dengan Pancasila dan UUD 1945, maka keberadaan Pesantren tersebut tetap sah dan tidak bisa dipersoalkan oleh siapapun juga. Realitas ini selaras dengan spirit dalam Konstitusi Indonesia. Secara konstitusional pendidikan merupakan hak setiap warga Indonesia, baik itu dari kalangan santri ataupun pelajar umum dijamin oleh Pasal 31 ayat 4 UUD NRI 1945. Konstitusionalitas keberadaan Pesantren ini tentunya perlu dibarengi dengan meratanya anggaran terhadap Pesantren sebagai salah satu institusi yang sah dalam dunia Pendidikan. Apalagi Fungsi Pesantren dalam UU 18 Tahun 2019 ini tidak hanya memiliki fungsi ansih Pendidikan saja, melainkan juga memiliki fungsi dakwah dan pemberdayaan masyarakat sebagaimana disebutkan dalam Pasal 4 UU Pesantren. Bahwa komitmen negara dalam memprioritaskan anggaran pendidikan sekurang-kurangnya 20\% dari APBN serta dari APBD untuk memenuhi penyelenggaraan pendidikan nasional juga harus diberlakukan secara proporsional terhadap Pesantren yang merupakan bagian dari dunia pendidikan. Sehingga penyebutan verbal numeral $20 \%$ anggaran pendidikan harus dialokasikan secara merata kepada semua komponen subsistem pendidikan, baik pada jenjang dan jenis pendidikan yang berbeda, dalam keseluruhan sistem pendidikan nasional, yang di dalamnya ada Lembaga Pendidikan Pesantren. APBN 20\% harus menempatkan pendidikan sebagai kultur investasi jangka panjang termasuk pendidikan agama di dalamnya Lembaga 
Pendidikan Keagamaan dan Pesantren. Sebagaimana halnya ditegaskan dalam 48 UU 18 Tahun 2019 yang mensyaratkan pendanaan Pesantren dapat berasal dari pemerintah Pusat, Pemerintah Daerah, sumbangan masyarakat, bahkan dapat berupa hibah dan kerjasama pesantren dengan luar negeri.

Penekanan pada pendidikan keagamaan merupakan salah satu tradisi dalam agama-agama yang ada di Indonesia dan menjadi perhatian utama para pemikir Muslim sejak dulu. Bahkan, target utama dan misi negara sebagaimana termaktub dalam pasal 28 E ayat (1) UUD 1945 "Setiap orang berhak memeluk agama dan beribadat menurut agamanya, memilih pendidikan dan pengajaran, memilih pekerjaan, memilih kewarganegaraan, memilih tempat tinggal diwilayah negara dan meninggalkannya, serta berhak kembali”. Sehingga tidak jarang persoalan pendidikan kegamaan seringkali dikaitkan dengan adanya pengaruh Westernisasi dan modernitas. Selain itu, pendidikan keagamaan juga merupakan tahap penyiapan pemimpin-pemimpin masyarakat serta guna mengatasi kemiskinan sumber daya alam dan manusia. Betapapun baiknya reformasi pendidikan, jika sistem pendidikan keagamaan belum diberikan ruang yang cukup besar terhadap dinamika kebangsaan maka akan sangat sulit dilahirkan situasi dan kondisi yang baik sesuai dengan kerangka epistemologi dan pandangan hidup bernegara. Dengan menekankan pendidikan keagamaan maka kekurangan yang terjadi saat ini terutama problematika kebangsaan dapat diperbaiki. Agar pendidikan dapat mengarah kepada pengembangan individu, maka sebuah pendidikan harus dapat merefleksikan dari insan kamil yang mengarah kepada pembentukan insan kamil. Hal inilah yang membedakan peran pendidikan keagamaan dengan pendidikan Barat yang hanya mencerminkan ketinggia logika manusia. Meskipun mereka juga mempunyai konsep universal, namun karena pengaruh paham humanisme sofistik yang kuat maka manusia diletakkan di atas segala-galanya. Ungkapan Protagoras yang sering mereka kutip adalah bahwa: "manusia adalah ukuran dari segala sesuatu, segala sesuatu yang ada adalah ada, dan segala sesuatu yang tidak ada adalah tidak ada". 6

Tentunya kenyataan ini berbeda dengan kenyataan sebelum disahkannya UU Pesantren. Tidak setaranya pengalokasian APBN ataupun APBD untuk Lembaga Pendidikan Keagamaan dan Pesantren, secara implementatif akan melahirkan disparitas anggaran yang cukup tinggi antara

${ }^{6}$ Doni Koesoema, Pendidikan Karakter, PT. Grasindo, Jakarta 2007 hlm 311. 
lembaga pendidikan yang formal dengan lembaga pendidikan informal, tentunya berdampak dalam peningkatan mutu antara lembaga pendidikan yang sejenis, khususnya berkaitan dengan penyediaan sarana dan prasarana. Realitas ini akan berimplikasi pada ketimpangan penganggaran. Di mana kondisi operasional lembaga pendidikan keagamaan diusahakan oleh masyarakat secara keseluruhan karena tidak mempunyai DIPA atau dana operasional yang jelas. Selain itu, pengajuan permohonan pembangunan Lembaga Pendidikan Keagamaan dan Pesantren terkendala oleh terbatasnya anggaran di Kementerian Agama dan tidak didukung oleh Pemerintah Daerah karena dianggap sebagai urusan yang bersifat vertikal.

\section{KESIMPULAN DAN PENUTUP}

pesantren merupakan lembaga Pendidikan tertua di Indonesia, namun dalam kenyataannya negara belum maksimal dalam memperdayakannya dibuktikan belum ada pengakuan yang kuat yang dilakukan oleh negara. Sehingga pensatren masih diposisikan sebagai lembaga non formal. Sehingga keberadaannya seperti dikesampingkan, terkesan negara hanya focus pada Pendidikan formal. Dari sini kemudian bisa dilihat dengan ketiadaan paying hukum yang kuat maka pesantren tidak bisa menikmati anggaran 20\% dari APBN. Dengan diterbitknyaa undang-undang tentang pesantren maka menjadi angin segar bagi Pendidikan pesantren karena Pendidikan pesantren sudah diakui dengan paying hukum yang kuat. Yang menjadi problem saat ini adalah belum ada mekanisme yang jelas seperti peraturan pemerintah sebagai tindaklanjut diundangkannya undang-undang tentang pesantren. Terutama terkait dengan proses pembiayaan pesantren juga terkait dengan mekanisme pembagiannya.

\section{BLIOGRAFI}

Arifin Junaidi, Pendidikan dan Bonus Demografi, makalah, disampaikan pada FGD Tasheh NA\&RUU Madrasah, 22-23 Juni 2016

Doni Koesoema, Pendidikan Karakter, PT. Grasindo, Jakarta 2007

Muhtar Said, Asas Asas Hukum Administrasi Negara, Thafa Media, Yogyakarta 2019.

Muhtar Said, Politik Hukum Tan Malaka, Thafa Media, Yogyakarta, 2013

Satya Arinanto, Politik Pembangunan Hukum Nasional Dalam Era Paska Reformasi: Jurnal Konstitusi Mahkamah Konstitusi, 2006 
Konstitusionalitas Pesantren Paska Disahkannya Uu 18 Tahun 2019

Sekretariat Jenderal MPR RI, Undang-Undang Dasar Negera Republik Indonesia Tahun 1945 (Jakarta, Setjen MPR RI, 2014), Cet.XIII

Undang - Undang Dasar 1945

Undang - Undang Nomor 18 Tahun 2019 tentang Pesantren

UU 12 Tahun 2011 sebagaimana diubah dengan UU 15 Tahun 2019 Tentang Perubahan UU 12 Tahun 2011 Tentang Pembentukan Peraturan perundang-undangan, materi muatan dalam aturan teknis tidak dapat mengatur anggaran dan atau mengatur materi Pidana 
Konstitusionalitas Pesantren Paska Disahkannya Uu 18 Tahun 2019 